\title{
Thrusting and debris entrainment in a surging glacier: Bakaninbreen, Svalbard
}

\author{
Michael J. Hambrey, \\ School of Biological and Earth Sciences, Liverpool John Moores University, Byrom Street, Liverpool L3 $3 A F$, England \\ Julian A. Dowdeswell, \\ Centre for Glaciology, Institute of Earth Studies, The University of Wales, Aberystwyth, Dyfed S123 3DB, Wales
}

Tavi Murray and Philip R. Porter

School of Geography, University of Leeds, Leeds LS2 9JT, England

\begin{abstract}
Bakaninbreen, a $17 \mathrm{~km}$ long glacier terminating in fjord waters in central Spitsbergen $\left(77^{\circ} 45^{\prime} \mathrm{N}, 17^{\circ} 20^{\prime} \mathrm{E}\right.$ ), began to surge between the springs of 1985 and 1986. By summer 1994 the surge front had reached a position $3 \mathrm{~km}$ from the terminus and had almost ceased propagation. Structural investigations were undertaken to characterise the tectonic evolution of this thermally complex surgetype glacier, and the role played by thrusting and its effect on debris entrainment. Much of the glacier surface, particularly within and below the surge front, displayed transverse high-angle thrusts, defined by discrete fractures bounded by coarse clear ice. Some fractures were associated with a film of mud, whereas in others a discrete layer of diamicton, with interstitial ice several decimetres thick, was evident. Within the surge front, and genetically related to the thrusts, was a number of shear zones several metres wide. These were defined by fine-grained ice that was the product of the grinding up of crystals during shear (mylonitization). Three main sedimentary facies are associated with the thrusts: mud, gravelly mud and clast-rich muddy diamicton. The diamicton has the character of basal glacial debris: grain-size distribution ranging from clay to cobble size, clasts with a predominance in the sub-angular and sub-rounded classes, and striated and faceted clasts. Hot-water drilling through the glacier revealed several englacial layers above the surge front, and debris brought up on the drill stem suggests a basal origin. At least some of these englacial layers are probably the sub-surface continuations of the thrusts. The observed facies indicate that the glacier is moving over a soft, deformable bed and that thrusting is an important process in transferring debris to the surface, especially when the surge front is propagating down-glacier.
\end{abstract}

\section{INTRODUCTION}

The role of thrusting in glaciers has been the subject of considerable debate, and in particular whether the process can lead to basal debris rising from the bed to an englacial and even supraglacial position. Evidence has been presented from polar regions that thrusting or discrete shearing in ice-marginal areas is an important process (e.g. Souchez, 1967; Hambrey and Müller, 1978). Thrusting is also a major feature of both temperate and polythermal surge-type glaciers. In the case of Variegated Glacier, Alaska, thrusting was observed to take place at the surge front during its 1982-83 surge (Sharp and others, 1988). Furthermore, basal debris layers beneath surgetype glaciers are thought to be largely tectonic in origin, resulting especially from folding and thrusting (Sharp and others, 1994). The sub-polar Trapridge Glacier, Yukon Territory, demonstrates the slow propagation of a wavelike bulge down-glacier, and the movement of basal debris towards the surface along thrusts that terminate within the body of the glacier, there being no surface expression of either thrusts or debris Clarke and Blake, 1991). On Svalbard tide-water glaciers of surge type, the changing stress regime of the active phase of the surge cycle has also been investigated Hodgkins and Dowdeswell, 1994). In the cold and polythermal glaciers that are typical of the Arctic, thrusts are commonly associated with large volumes of debris that are demonstrably of subglacial origin. This paper considers this aspect of deformation with reference to a surging glacier as it approaches the end of its active phase.

The manner in which debris is entrained is important for several reasons. First, it provides evidence of basal conditions, in terms of both the rigidity of the substrate and the variable nature of unconsolidated material over which the glacier flows. Secondly, the relation between debris layers and structures is useful in assessing the deformation regime within an ice mass. Thirdly, the transfer of debris from the bed to the surface is important in understanding how certain sediments and depositional 
landforms develop, especially supraglacial flow till, hummocky moraine and thrust-moraine complexes. A surge of Bakaninbreen, Svalbard, has provided a unique opportunity to examine these processes in a modern Arctic glacier, and may serve as an analogue for the glaciers and ice sheets of the last glaciation that produced many of the landforms observed today in more southerly latitudes.

\section{AREA OF INVESTIGATION}

Svalbard is a region of the high Arctic where glacier surges are commonplace, although glaciers here often have an active phase lasting a number of years and a correspondingly long quiescent phase (Dowdeswell and others, 1984, 1991; Hagen, 1987; Hagen and others, 1993). Bakaninbreen is a $17 \mathrm{~km}$ long valley glacier, draining a basin covering almost $60 \mathrm{~km}^{2}$. For the lower $6.5 \mathrm{~km}$ it flows parallel to the larger Paulabreen, a large medial moraine defining the boundary between the two glaciers. Bakaninbreen terminates both in the shallow fjord waters of Rindersbukta, and on the adjacent slopes that are mantled with debris originating from a former surge (Punning and others, 1976; Fig. 1).

The bedrock underlying Bakaninbreen comprises sandstone and friable mudstone of Cretaceous to Palaeogene age (Salvigsen and Winsnes, 1987). These rocks break down readily under the influence of frost action and subsequent transport by ice. Frequent debris slides from the surrounding mountains add a large amount of supraglacial debris to the glacier surface, much of which is buried within the accumulation area and subsequently deformed as the ice moves downwards. Surging glaciers in Svalbard may be preferentially situated on soft sedimentary bedrock, suggesting that there is a link between the ability of a glacier to form a thick basal debris layer and the substrate (Hamilton and Dowdeswell, 1996).

A series of aerial photographs acquired by the Norsk Polarinstitutt between 1936 and 1977 shows

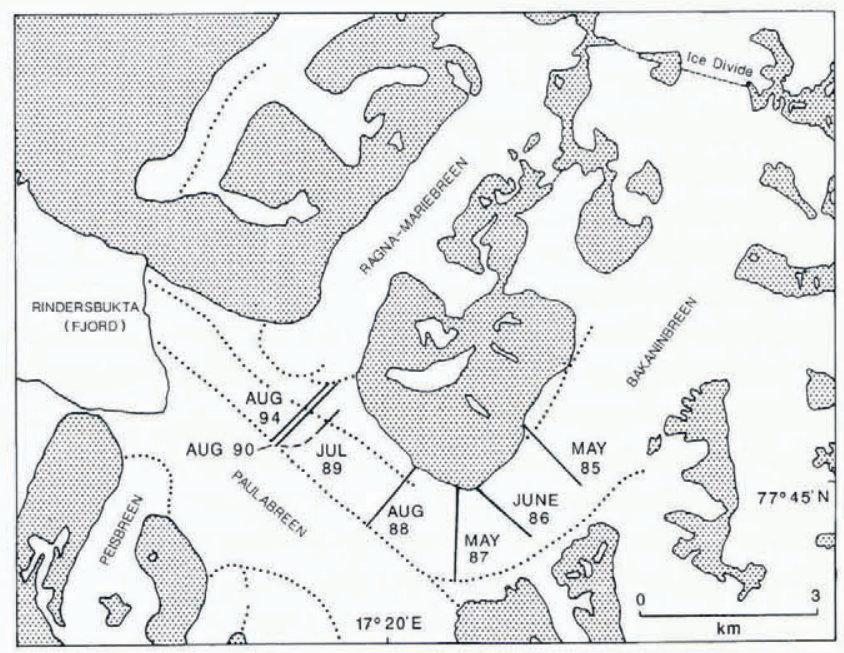

Fig. 1. Location map of Bakaninbreen, Svalbard, showing movement of surge front down-glacier (after Dowdeswell and others, 1991).
Bakaninbreen to be in its quiescent phase. In 1985 the first evidence of surging in the reservoir area was observed in the field, and by 1986 the surge was well under way (Dowdeswell and others, 1991). During the succeeding period, the surge front propagated downglacier, initially at rates in excess of $1 \mathrm{~km}^{-1} \mathrm{yr}^{-1}$ (Fig. 1), and the glacier surface upstream became heavily crevassed. The last series of aerial photographs, taken in August 1990, indicates that the surge front had reached a position approximately $3 \mathrm{~km}$ from the terminus. Since that time there has been only about a further $200 \mathrm{~m}$ of propagation of the front downglacier. The heavily crevassed area behind the front had almost entirely ablated away by the summer of 1994 when the present investigation took place. The area investigated lay between the top of the surge front and the glacier terminus. Detailed studies of all structures were undertaken, although the main emphasis here is given to the thrusts and associated phenomena (Figs 2 and 3).

\section{METHODS}

The structure of Bakaninbreen was investigated by means of (i) aerial photographic analysis (especially at the scale of $1: 15000$ ), and (ii) field identification and three-dimensional orientation measurements of the planar ice structures, which included sedimentary stratification, longitudinal foliation and several sets of fractures. The orientations of the thrusts were measured on a series of transverse profiles above, within and below the surge front, and along longitudinal profiles through the surge front in three of the constituent flow units. Data from these profiles were plotted on equalarea stereographic projections. Attention was paid to the crystal structure and debris content of the thrusts. Clasts were analyzed for Powers' roundness, and the data plotted for comparison with the different glacial settings documented by Dowdeswell (1986). Surface features on clasts, such as striae and faceting, were also recorded.

\section{STRUGTURAL GLAGIOLOGY}

\section{Morphology of the surge front, 1994}

By August 1994, the formerly near-vertical, strongly convex, heavily crevassed surge front had ablated to a gentle ramp approximately $50 \mathrm{~m}$ high, although the upper limit was poorly defined. Three longitudinal profiles, one in each of the principal constituent flow units, were measured (Fig. 4). A prominent convex profile through the surge front was only evident towards the base of flow unit C; this had a maximum slope of $20^{\circ}$. Flow units A and B had uneven profiles but with hints of the remnants of two bulges (which appear more prominently in the 1990 aerial photographs). The maximum angles in flow units $\mathrm{A}$ and $\mathrm{B}$ were $13^{\circ}$ and $11^{\circ}$, respectively. Numerous structures were evident in this area, of which the transverse structures are shown in Figure 4 . 

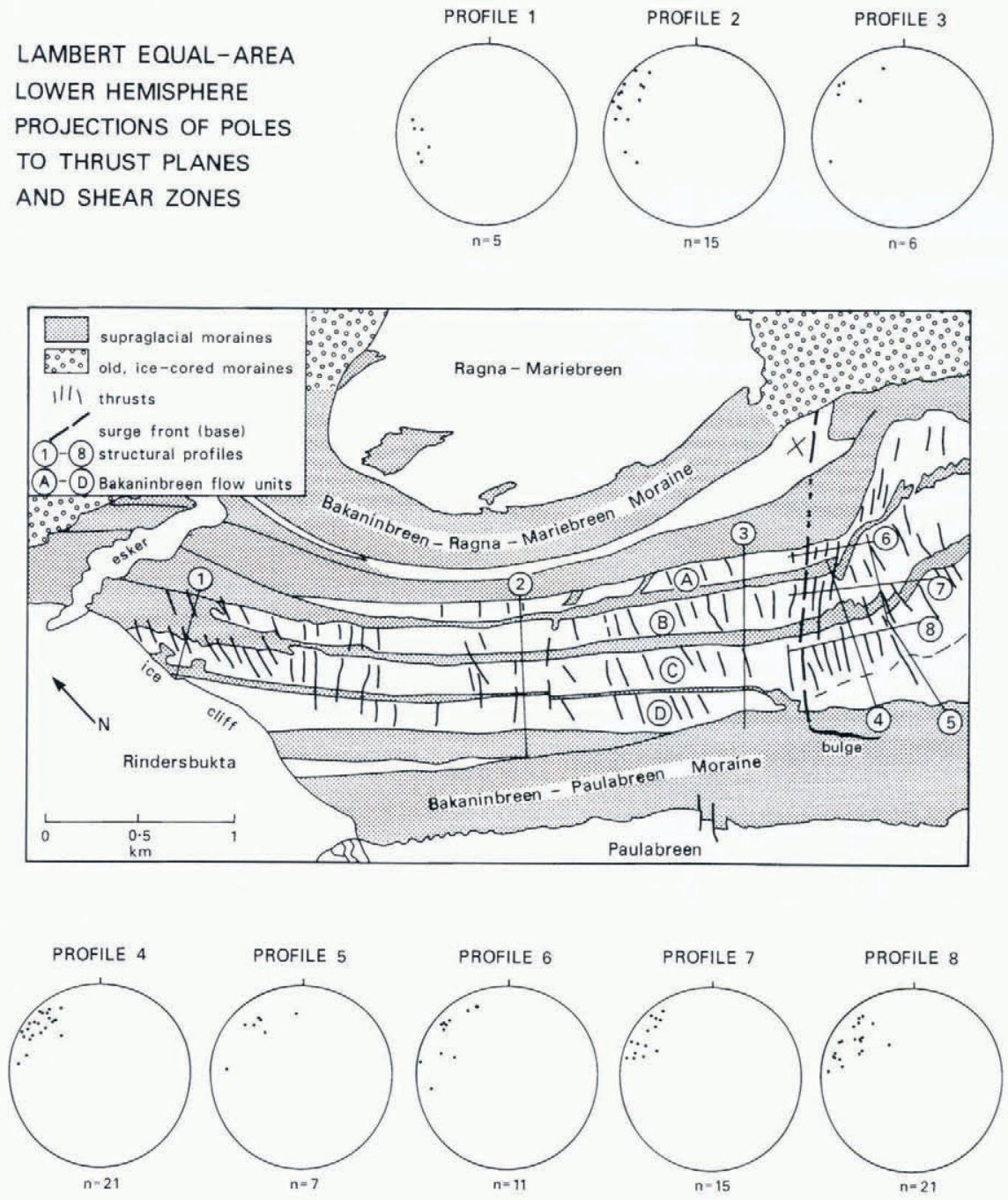

Fig. 2. Outline map of moraines and thrusts on Bakaninbreen, based on 1990 aerial photograph, showing the sector from the surge front to the terminus. Structural profiles are illustrated with accompanying Lambert equal-area stereographic projections of thrust-and shear-zone orientation data.

\section{Structural sequence}

The progressive development of structures in Bakaninbreen may be related broadly to quiescent-phase ductile deformation and surge-related brittle fracture, as has been demonstrated for Variegated Glacier (Lawson and others, 1994). In the vicinity of the surge front the following structures, listed in order of their inferred development, are present (Fig. 5):

(1) Sedimentary stratification with debris layers, formed in the accumulation area and carried down with little deformation during surges. This structure remains sub-horizontal, but has a highly variable strike. The debris is mainly angular and suggestive of a rock-fall origin.

(2) Longitudinal foliation, defined by intercalated layers of coarse bubbly, coarse clear and fine ice. This structure pervades most of the glacier, and is aligned parallel to moraines formed by internal deformation during quiescent-flow stages. Disruption and bending of this structure has taken place during surging.

(3) Strong deformation of stratification, in the form of chevron folding and associated with longitudinal compression, is observable locally at the surge front. A transverse axial-plane foliation, reminiscent of slaty cleavage in rocks, is developed within the northern part of the bulge. This foliation may originally have been longitudinal as (2), but was rotated to a transverse orientation as the surge front passed through.

(4) Thrusting- and shear-zone development, associated with the passage of the surge front (a compressive wave) through the glacier.

(5) Longitudinal fracturing, especially evident in the form of short crevasses or tensional veins, developed as the surge front passes through.

6) High-angle transverse faults, formed in the lower part of, and below, the bulge. From the morphology of their outcrop at the surface (overhanging wall facing up-glacier), the lower wall appears to have been displaced upwards relative to the up-glacier wall.

Structures (1) and (2) are related to quiescent-phase deformation, and (3) to $(6)$ to surge-phase deformation. Basal debris is associated mainly with (4) and to a lesser 

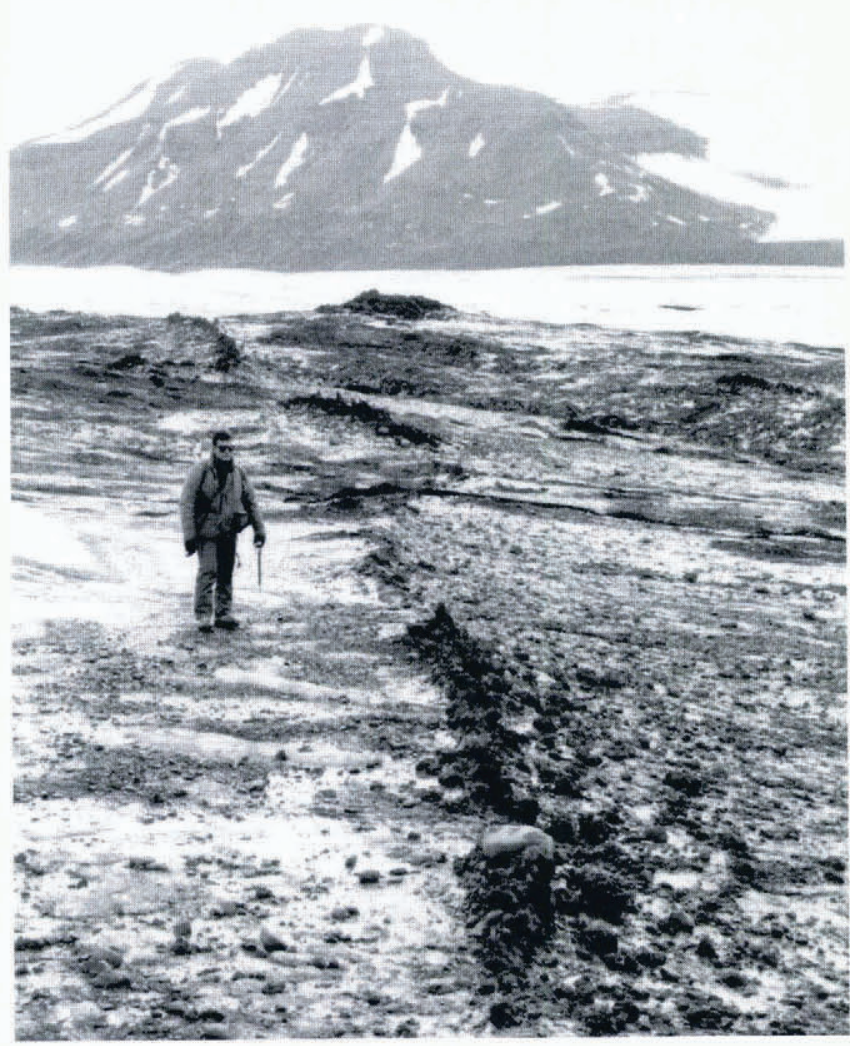

Fig. 3. A transverse, steeply dipping, debris-bearing thrust ridge extending across the surface of Bakaninbreen a few hundred metres above the terminus. The predominance of sub-angular and sub-rounded clasts, many of which are faceted and striated, indicates a basal derivation. The white ice in the background belongs to Paulabreen. August 1994 pholograph. degree with (3), while supraglacial debris is associated with (1) and (2).

\section{Surface expression of thrusts and related phenomena}

Distribution and spacing of thrusts

Fractures, commonly extending for 50-100 m (and sometimes more) across the glacier surface in a transverse direction and dipping steeply up-glacier, are interpreted as thrusts. They are best developed within the surge front and near the terminus, but examples occur throughout the length of the lower glacier. The spacing of these fractures is mainly in the range $50-200 \mathrm{~m}$, but a particularly well-developed set with a spacing of about $1 \mathrm{~m}$ occurs halfway down the bulge. Some thrusts pass laterally into well-developed shear zones within the bulge. Below the surface of the glacier, preliminary radio-echo sounding and drillhole data indicate that these thrusts extend to the bed of the glacier.

\section{Composition}

Thrusts are prominent features at the ice surface because of their association with coarse clear ice, which melts more quickly than the adjacent coarse bubbly ice. The thrust itself is usually marked by a discrete planar discontinuity, on either side of which the clear ice extends for several centimetres, thence passing transitionally into the bubbly ice. The coarse clear-ice layers attain a width of $30 \mathrm{~cm}$, and probably represent zones of recrystallization associated with the displacements. Thin films of mud commonly occur along the thrust plane. Mud may also be disseminated within the coarse clear-ice

WNW

ENE
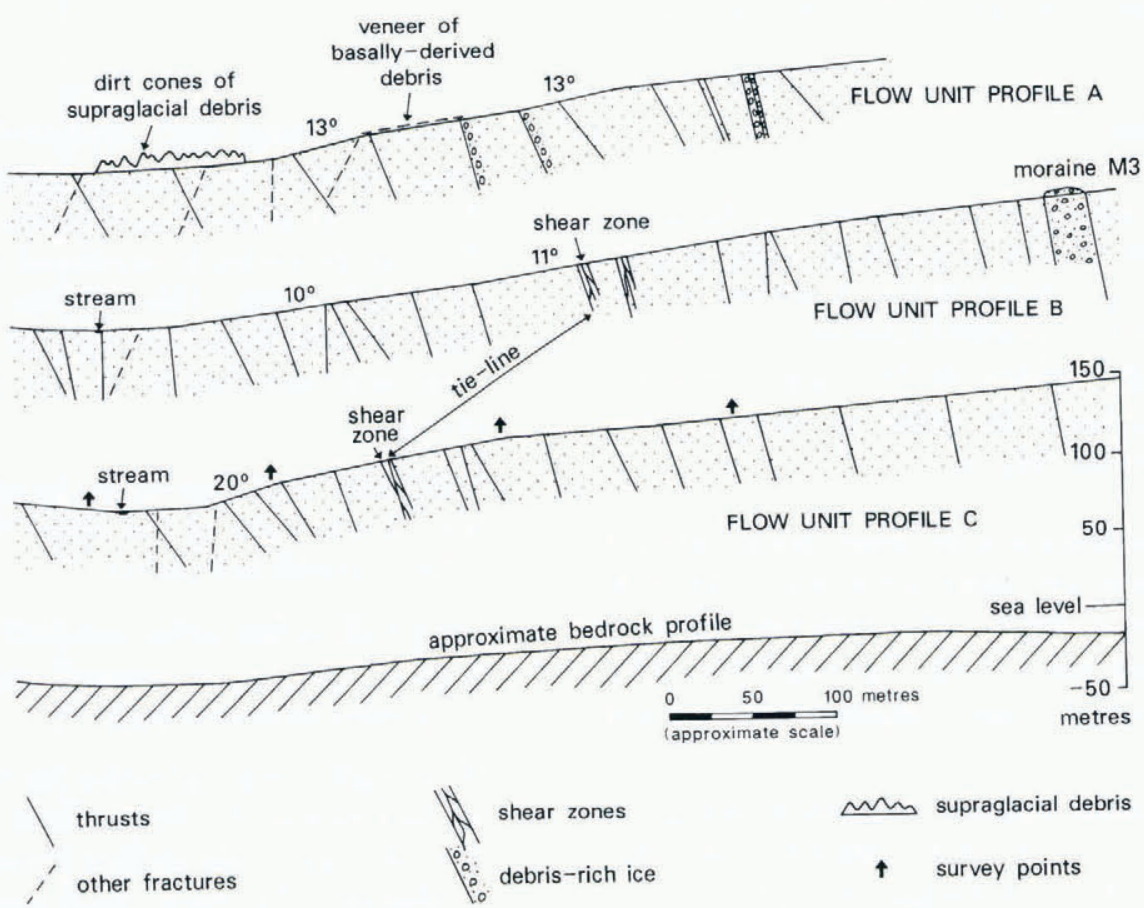

supraglacial debris

$\uparrow \quad$ survey points

Fig. 4. Longitudinal profiles through the thrusts and down-glacier-dipping transverse faults in the surge-front bulge of August 1994, combining surface observations with radio-echo-sounding data from flow unit C. Only those thrusts whose orientations were measured are illustrated; they represent a small proportion of the total visible at the surface. Maximum slope angles are indicated. 


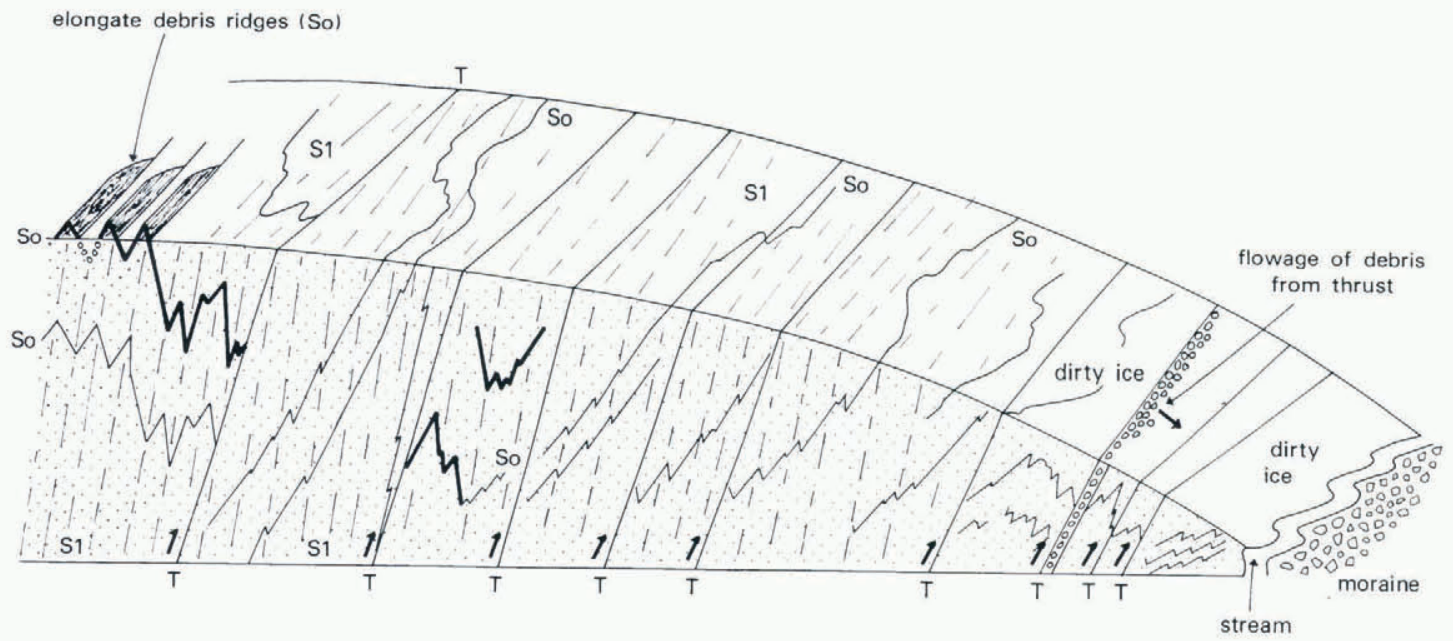

$\mathcal{W}^{\text {so Stratification }}$

MW So Stratification

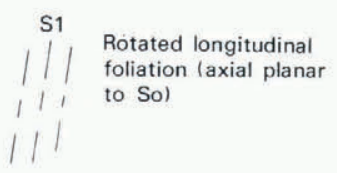

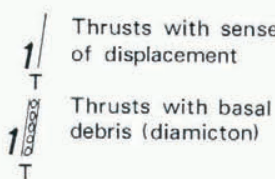

T

Fig. 5. Schematic three-dimensional sketch of a section through the surge front where it has impinged on the large medial moraine on the north side of the glacier as revealed in the walls of partially ablated longitudinal crevasses. The main structures are chevron-folded stratification with a near-vertical axial-plane foliation, intersected by high angle thrusts of slightly different orientation.

zones. Also observed were less well-defined thrust zones, up to $0.5 \mathrm{~m}$ wide, comprising debris-rich ice very similar to dirty basal ice (cf. Sharp and others, 1994). From this ice, debris ranging in size from mud to cobble was melting out (Fig. 3). Several thrust zones of similar width, comprising near-solidly frozen diamicton with interstitial ice, appear to have been uplifted directly from the basal layer of the glacier.

\section{Sense of displacement}

The magnitude and sense of displacement of thrusts could sometimes be gauged from the manner in which gently dipping structures, such as stratification, are displaced upwards above the fracture and folded. These are best observed in longitudinal stream channels. Visible displacements of a few decimetres to metres are common, but much larger displacements are probable, although not decipherable, because of the small scale of the exposed sections. In addition, distinct groups of foliae within the longitudinal foliation locally show lateral displacements of several centimetres towards the right. These thrusts, therefore, represent oblique-slip fractures, the lateral component being due to movement of ice during the surge around a $90^{\circ}$ bend $6-7 \mathrm{~km}$ from the present glacier terminus.

\section{Orientation and down-glacier modification of Ihrusts}

The majority of thrusts dip up-glacier at a high angle irrespective of position on the glacier, with $50 \%$ falling in the range $70-80^{\circ}$ (Fig. 6). This orientation is quite different from the angle of dip of thrusts in non-surging glaciers, where angles less than $45^{\circ}$ are more typical. Thrusts tend to have a straight or slightly curved surface expression; some are anastomosing, while others cut across each other. A few extend diagonally down- glacier. Some thrusts pass through medial moraines into adjacent flow units. There is little difference in orientation between the margins and the middle, and there is little indication of significant rotation to a lower angle downglacier, as indicated by the consistency of data in stereographic projections for both transverse and longitudinal profiles (Fig. 2). In fact, there is a remarkable uniformity of orientation of thrusts throughout the glacier from the surge front to the snout (Fig. 6). This suggests that, once these structures have formed, shearing at the margins and base of the glacier is small, otherwise curvature of the thrusts would be more pronounced. Rather, the thrusts are transmitted downwards mainly during surge phases.

\section{Shear zones}

Of similar orientation to the thrusts are two prominent and several lesser zones comprising intercalated fine- and coarse-grained ice. These zones are confined to the middle and upper parts of the surge front, and are best developed on its northern side. The fine-grained ice consists of dense bubbly ice with bubbles up to $1 \mathrm{~mm}$, slightly elongated parallel to the shear zone. Finely disseminated mud gives a brownish hue to this ice and, in places, it is parallel to a diffuse foliation defined by bands of clear ice, a few millimetres across. Coarse clear ice (with crystals up to $5 \mathrm{~cm}$ in diameter) forms irregular to sharp boundaries with the fine ice, and includes disseminated clots of mud up to $1 \mathrm{~cm}$ in diameter, and scattered pebbles. However, the amount of recognisable basal debris is limited. Isoclinal folding of different ice types within the shear zones was observed after washing the surface of the glacier. The axial planes of such folds are themselves parallel to the shear zones. The largest shear zones measure $2 \mathrm{~m}$ across and have somewhat irregular 


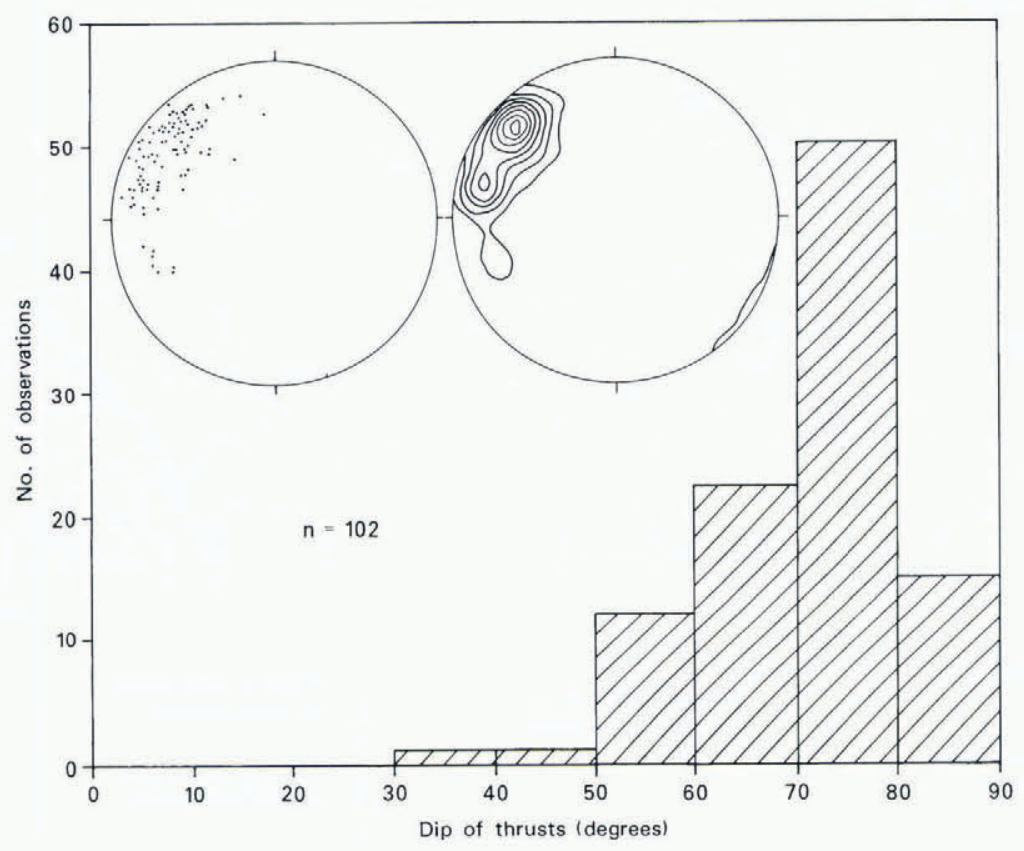

Fig. 6. Histogram illustrating the variability in the up-glacier dip-angle of all measured thrusts in Bakaninbreen. Inset: poles to all measured thrust planes and shear zones $(n=102)$, plotted on lower hemisphere Lambert equal-area projection; contoured distribution of poles to these structures, with contour intervals of $2 \%$ per $1 \%$ of area.

boundaries, although their orientation is consistent with the adjacent thrusts into which they pass. In one case, part of the glacier had clearly been washed by water emanating from the shear zone.

The shear zones are genetically related to the thrusts, but instead of being associated with a clean fracture, they appear to be the product of mylonitization of coarsely crystalline ice into fine-grained ice, associated with simultaneous development of shear-parallel folds and foliation. Post-shear recrystallization probably occurred subsequently, fine ice being progressively replaced by coarse clear ice. Thin sections and ice-crystal fabric measurements would provide useful information concerning these inferred processes.

Prominent lateral displacements are associated with the two widest shear zones and, where they intersect medial moraines, show a shift of 3-5 $\mathrm{m}$, accompanied by bending of the longitudinal foliation.

\section{SEDIMENTOLOGY OF THRUST FACIES}

Sediment associated with thrusts at the glacier surface includes mud and diamicton (Fig. 3). The mud varies from a cohesive sediment of uniform grain-size, to poorly sorted sediment with minor sand and gravel. This material forms either small ridges (about $0.1 \mathrm{~m}$ high) or shallow depressions in the ice according to its efficacy in protecting the ice from ablation. The diamicton comprises material from clay to cobble size, with rare boulders, and may be classified as "clast-rich muddy diamicton" (according to the modified Moncrieff (1989) classification in Hambrey (1994)). In places, the diamicton forms ridges up to $1 \mathrm{~m}$ high on the glacier surface and, when it dries out, it appears to retain its textural integrity as a non-stratified, compact material.
Down-glacier of the thrust, this material is remobilised with melting ice to form extensive areas of debris flows (cf. Lawson, 1982). The clasts are of limestone and sandstone, and were examined for shape and surface texture. All shapes from angular to rounded were present. Numerous clasts were striated and faceted.

In terms of the total glacier mass, the proportion of debris in thrusts is tiny; it is impossible to quantify as yet, as the densest debris concentration is likely to be near the bed, out of sight.

We interpret the sediment as having been subglacially derived. The mud at the surface is similar to mud recovered from the basal layer during hot-water drilling. Since the bed throughout the length of the sector of the glacier studied is below sea level, it is likely that this mud was of glaciomarine origin. In contrast, the diamicton has the characteristics of material carried in the zone of traction (cf. Boulton, 1978), notably grain-size distribution from mud to boulders, clast shape dominated by sub-rounded and sub-angular categories, and clast surface features such as facets and striations. This diamicton is therefore probably uplifted basal debris, entrained by regelation at the glacier bed, especially where the state of the bed passes from sliding or deformable to frozen. In a few ridges the uplifted sediment may be recycled subglacial till.

\section{MODEL OF DEBRIS ENTRAINMENT}

The passage of a surge front through a typical polythermal glacier such as Bakaninbreen is accompanied by the development of thrusts and shear zones which break out at the surface at a high angle (Fig. 7). In comparison with observations on Variegated Glacier (Lawson and others, 1994), a new thrust propagates 
(a) PRE-SURGE

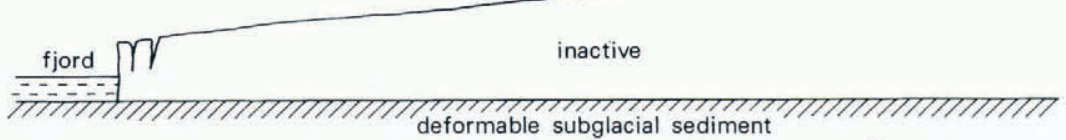

deformable subglacial sediment

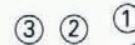

(b) DURING SURGE

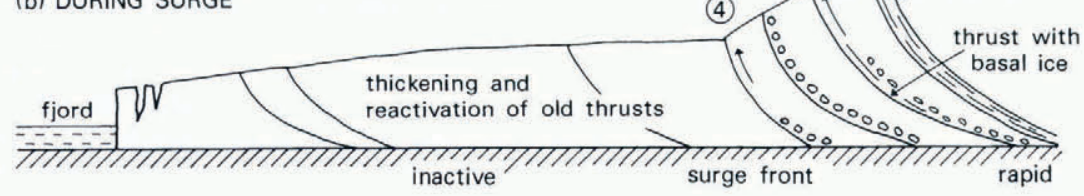

(c) SURGE REACHES SNOUT

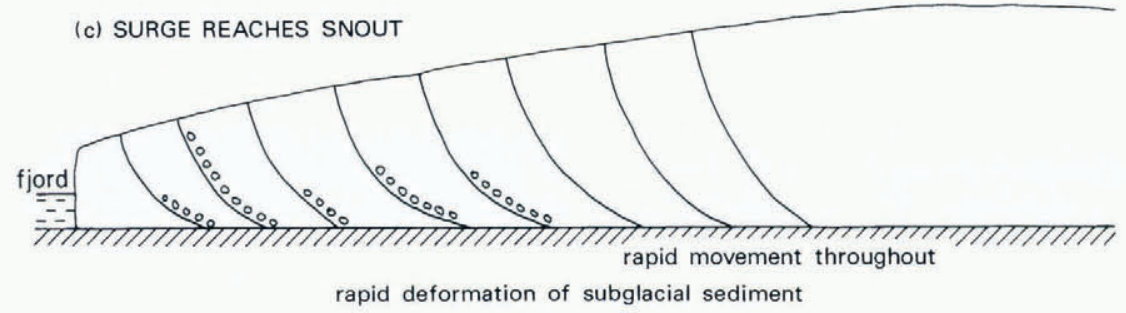

(d) DEPOSITION OF SEDIMENT AND INUNDATION BY SEA

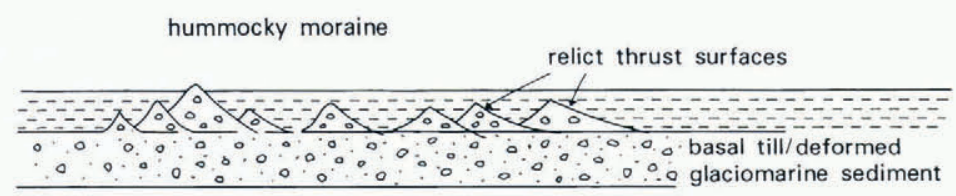

Fig. 7. Schematic illustration of development of thrusts and shear zones during a surge, the associated entrainment of debris from the glacier bed, and its transfer to the surface by thrusting during surge-front propagation. The morphology of the resulting landforms is also shown.

further forwards of the previous one, and provides a mechanism whereby the surge front can move downglacier at a rapid rate. From the character of the debris which arrives at the surface via some of these thrusts, it is evident that the thrusts extend to the glacier bed. Furthermore, the substrate at Bakaninbreen is likely to be not bedrock but deformable sediment of two types: basal till similar to that reported from Trapridge Glacier (Clarke and Blake, 1991), and glaciomarine mud. These two facies form the initial plane of décollement from which thrusts propagate upwards through the ice, allowing material which adheres to the base of the glacier by freeze-on to move upwards immediately above the thrust plane. Alternatively, unfrozen debris may move along the thrust plane and refreeze englacially. In most cases debris does not reach the surface, but when it does, it melts out and in its wet state flows across the glacier surface.

As the surge front propagates towards the terminus, old thrusts may become reactivated. Following the passage of the bulge, those thrusts which had already formed are transported passively; they are not subject to any significant internal deformation. This supports the view that, during a surge, most movement is accomplished by sliding.

Following the surge, the ice stagnates in situ. The debris incorporated along thrusts is released to form hummocky moraine (Fig. 7d), reflecting the variable concentration of debris in the ice, although short linear moraine elements preserve the form and orientation of the debris-laden thrusts.

This topography may be superimposed either on the basal glacial layer or on ice, the latter giving rise to a kettled topography and partially undermining the ridges. This type of landform assemblage may be seen in association with many surge-type glaciers, including that of the Paulabreen-Bakaninbreen complex from an earlier surge.

\section{CONCLUSIONS}

The gradual cessation of a 9 year long surge of polythermal Bakaninbreen, Spitsbergen, has provided an opportunity to study the structural evolution of a glacier as a surge front passes through, and the role this process plays in debris recycling. The following conclusions may be drawn:

(1) Propagation of the surge front is at least partially accomplished by the development of thrusts which break the glacier surface at a high angle.

(2) The relatively straight transverse orientation of thrusts is indicative of plug-flow (near-uniform velocities across the greater part of a transverse profile).

(3) Thrusts down-glacier of the surge front, which may have been formed during previous surges, are reactivated as a new surge front approaches. 
(4) Debris derived from the substrate is incorporated within basal ice and lifted upwards through the glacier along thrusts, in some cases reaching the surface, forming distinct linear ridges, from which debris flows across the ice surface.

(5) Two main facies, mud of probable glaciomarine origin and diamicton (basal till) are involved, and indicate that the glacier is moving over a soft, deformable bed.

(6) Thrusts pervade much of the glacier, although some are derived from earlier surges. They have a fairly constant orientation, and their lack of modification downstream suggests that very little downward movement in the lower part of the glacier is accomplished by internal deformation.

(7) Debris-bearing thrusts in the ice explain the origin of the landform assemblage commonly found below surge-type glaciers, namely aligned hummocky moraine ridges superimposed on kettle-hole topography.

\section{AGKNOWLEDGEMENTS}

This work was funded by European Union Environment Programme grant EN5V-CT93-0299. Financial support was also received from Liverpool John Moores University (M.J.H.). For assistance with the field-work we thank D. Garbett.

\section{REFERENCES}

Boulton, G.S. 1978. Boulder shapes and grain-size distributions as indicators of transport paths through a glacier and till genesis. Sedimentology, 25 (6), 773-799.

Clarke, G. K.C. and E.W. Blake. 1991. Geometric and thermal evolution of a surge-type glacier in its quiescent state: Trapridge Glacier, Yukon Territory, Canada, 1969 89. J. Glaciol., 37 (125), 158-169.

Dowdeswell, J. A. 1986. The distribution and character of sediments in a tidewater glacier, southern Baffin Island, N.W.T., Canada. Arct. Alp. Res., $18(1), 45-56$.

Dowdeswell, J.A., D.J. Drewry, O. Liestol and O. Orheim. 1984. Airborne radio echo sounding of sub-polar glaciers in Spitsbergen. Nor. Polarinsl. Skr. 182.

Dowdeswell, J. A., G. S. Hamilton and J. O. Hagen. 1991. The duration of the active phase on surge-type glaciers: contrasts between Svalbard and other regions. J. Glaciol., 37 (127), 388-400.

Hagen, J. O. 1987. Glacier surge at Usherbreen, Svalbard. Polar Res., $52,239252$.

Hagen, J. O., O. Liestol, E. Roland and T. Jörgensen. 1993. Glacier atlas of Svalbard and Jan Mayen. Nor. Polarinst. Medd. 129.

Hambrey, M.J. 1994. Glacial environments. London, UCL Press.

Hambrey, M.J. and F. Müller. 1978. Structures and ice deformation in the White Glacier, Axel Heiberg Island, Northwest Territories, Canada. J. Glaciol., 2082 , 41-66.

Hamilton, G.S. and J. A. Dowdeswell. 1996. Controls on glacier surging in Svalbard. 7. Glaciol., 42 140), 157-168.

Hodgkins, R. and J.A. Dowdeswell. 1994. Tectonic processes in Svalbard tide-water glacier surges: evidence from structural glaciology. J. Glaciol., 40 (136), 553-560.

Lawson, D. E. 1982. Mobilization, movement and deposition of active subaerial sediment flows, Matanuska Glacier, Alaska. J. Geol., 90 (3), 279-300.

Lawson, W.J., M.J. Sharp and M.J. Hambrey. 1994. The structural geology of a surge-type glacier. F. Struct. Geol., 16 10), 1447-1462.

Moncrieff, A.C. M. 1989. Classification of poorly sorted sedimentary rocks. Sediment. Geol., 65, 191-194.

Punning, J. -M., L. Troitsky and R. Rajamäe. 1976. The genesis and age of Quaternary deposits in the eastern part of Van Mijenfjorden, West Spitsbergen. Geol. Fören. Stockholm Förh., 98 4), 343-347.

Salvigsen, O. and T.S. Winsnes. 1987. Geological Map of Svalbard 1:100,000. C10G. Braganzavågen. Oslo, Norsk Polarinstitutt.

Sharp, M., W. Lawson and R.S. Anderson. 1988. Tectonic processes in a surge-type glacier. F. Struct. Geol., 10 5), 499-515.

Sharp, M., J. Jouzel, B. Hubbard and W. Lawson. 1994. The character, structure and origin of the basal ice layer of a surge-type glacier. $\mathcal{J}$. Glaciol., $40(135), 327-340$.

Souchez, R. A. 1967. The formation of shear moraines: an example from south Victoria Land, Antarctica. J. Glaciol., 6 (48), 837-843. 